\title{
An Interferometer Procedure Applied to the Study of the Chemical Durability of Silicates, Enamels, and Metals
}

\author{
Robert G. Pike and Donald Hubbard
}

\begin{abstract}
The chemical durability of quartz, fused silica, obsidian, flint, opal, and glass were determined by the interferometer method and the results interpreted in the light of the Donnan theory of membrane equilibria. A more sensitive test of the same phenomena is the uneven distribution of migratable ions, as shown by the $\mathrm{Ag}^{+} \mathrm{Br}^{-}$titration. The tests used are sensitive enough to differentiate between the different types of silica and may be applicable to the study of the chemical weathering characteristics of all natural silicates. Results of preliminary experiments on enamels and metals show that these tests may serve as indicators of the corrosive resistance of these materials under a wide range of conditions
\end{abstract}

\section{Introduction}

The results reported in earlier publications have demonstrated the utility of the interferometer procedure for determining the chemical durability of glasses, particularly in the study of the voltage anomalies of the glass electrode $[1,2] .{ }^{1}$ These results suggested that the same procedure could be used to determine the relative chemical durability of natural minerals and thus throw some further light on the probable mechanism and rate of chemical weathering in nature.

Another investigation has also been described which shows that there is an uneven distribution of migratable ions at a glass-solution interface in accordance with the dictates of the Donnan theory of membrane equilibria [3]. In view of these findings it seemed desirable to determine if the same principles could be applied to some of the natural silicates.

With these objectives in mind, quartz, fused silica, opal, obsidian, flint, and pitchstone were chosen for study. The glasses, Pyrex brand chemical ware 7740 (hereafter referred to as Pyrex) and Corning 015, on which many tests had previously been made, were also included in the study as control and comparative samples.

The results obtained in the first experiments suggested that the interferometer procedure might have even wider applicability. Therefore, the, the method was extended to the study of porcelain enamels and metals.

\section{Experimental Procedure}

\subsection{Interferometer Method}

When available, specimens about $1 / 2$ by $3 / 4$ in. were ground flat on a cast-iron lap with fine alumina powder and polished on a wax wheel with levigated alumina. These specimens were treated for chemical durability by the interferometer procedure $[1,2]$. This consists of immersing the sample one-half its depth in a solution of known $\mathrm{pH}$ covered with an oil ayer to prevent evaporation of the water, and main-

\footnotetext{
${ }^{3}$ Figures in brackets indicate the literature references at the end of this paper.
}

tained at a temperature of $80^{\circ} \mathrm{C}$ for definite periods of time. Using the unexposed portion of the sample as a reference plane, the attack on the exposed surface is measured by determining the displacement of the interference fringes with the conventional Pulfrich viewing apparatus, using an unfiltered helium lamp for illumination. Swelling of the surface is plotted in all figures as negative attack. To make the results comparable with previous publications $[1,2,3,6]$ the exposures were made at $80^{\circ} \pm 0.2^{\circ} \mathrm{C}$ for $6 \mathrm{hr}$ to Britton-Robinson universal buffer solutions [4] (hereafter called Britton buffers) ranging from $\mathrm{pH} 2$ to $\mathrm{pH}$ 11.8, with some exceptions as explained later in the text.

\subsection{Hygroscopicity}

Th s procedure for determining hygroscopicity was that reported in previous publications $[6,2]$, which consisted of weighing the water sorbed [5] upon exposing about $1.5 \mathrm{~g}$ of powdered glass (passed through a U. S. Standard Sieve No. 140) to the high humidity (approximately 98 percent) maintained by a saturated solution of $\mathrm{CaSO}_{4} \cdot 2 \mathrm{H}_{2} \mathrm{O}$. To insure speed in obtaining equilibrium and uniformity throughout the humidity chamber, the walls were lined with a blotter wick, and the atmosphere of the closed system kept circulating with a fan. The samples were exposed for 1 - and 2 -hr periods at $25^{\circ} \mathrm{C}$ and the results reported as milligrams of water sorbed per cubic centimeter of sample.

\subsection{Uneven Distribution of Migratable Ions}

For the experiments on the uneven distribution of migratable ions between the outer solution and the silica rich layer of the specimens, samples of approximately $10 \mathrm{~g}$ were prepared by being crushed and passed through a No. 50 and retained on a No. 140 U. S. Standard Sieve. They were then leached for various periods of time at $\mathrm{pH} 4.1$ and $80^{\circ} \mathrm{C}$ with occasional agitation. After rinsing and decanting the samples twice, they were treated by agitation for $5 \mathrm{~min}$ in $50 \mathrm{ml}$ of saturated $\mathrm{Ag}\left(\mathrm{NH}_{3}\right)_{2} \mathrm{Br}$ solution [3]. The samples were then separated by decantation from the liquid phase. The sample and liquid phases were acidified with concentrated $\mathrm{H}_{2} \mathrm{SO}_{4}$ and titrated 
potentiometrically for excess $\mathrm{Ag}^{+}$remaining in the gelatinous silica-rich surface and for the excess $\mathrm{Br}^{-}$ ions appearing in the outer solution [3].

\subsection{Materials}

Flint samples were cut from the black center portion of a nodule from Travis County, Tex. Pitchstone was from Georgetown, Colo. Obsidian was a typical natural black glass. These three materials were obtained through the courtesy of Edward P. Henderson at the United States National Museum. Quartz samples were cut from a near optical grade crystal. Fused silica was commercial optical grade. Opal from Nevada was obtained through Wards Natural Science Establishment. Pyrex was chemical glassware 7740. Enameled metalware samples were regular commercial grade, furnished by the Enamel Metals Section of the National Bureau of Standards. Metal specimens were commercial samples.

\section{Results and Discussion}

\subsection{Silicates}

The extent of surface alteration (swelling or attack) at various $\mathrm{pH}$ values has been demonstrated with certain glasses $[1,2,3]$. The swelling has been rationalized in terms of the Donnan theory of membrane equilibria [3], and the attack in terms of rate of solution of silicates. In the figures the amount of swelling is plotted as negative attack. Quartz, flint, obsidian, and fused silica show no detectable swelling or attack at $\mathrm{pH}$ values below 9.5. Above this value, the rate of attack increases to $1 / 2$ fringe at $\mathrm{pH} 11.8$ for fused silica. The difference between the fused silica and crystalline quartz is easily demonstrated (fig. 1 data given in table 1). The fact that obsidian, a natural glass, falls between the two in chemical durability is perhaps surprising but may possibly be a result of a high-alumina content characteristic of obsidian glass. The attack on flint and crystalline quartz was not detectable at $\mathrm{pH} 11.8$ after a $6-\mathrm{hr}$ exposure. However, there is a detectable attack after $24 \mathrm{hr}$.
A sample of the crystalline quartz was also given an exposure of 2 weeks at $80^{\circ} \mathrm{C}$ in $\mathrm{pH} 4.1$ and showed a definite swelling at the contact of the solution oil surface. Longer exposure times could be used if a method could be found to prevent diffusion of the water through the oil layer.

In order to show more clearly the relative resistance to attack in strong alkalies, the samples were also treated for $6 \mathrm{hr}$ in 5 percent $\mathrm{NaOH}$ at $80^{\circ} \mathrm{C}$ and the results listed in table 1 . (Because of the very low resistance of opal it was treated for only $15 \mathrm{~min}$ and the results extrapolated to $6 \mathrm{hr}$.)

The Corning 015, a glass of poor chemical durability, is included as a means of comparison with previous tests on optical glasses.

The results obtained on opal are the most interesting of the group. Swelling of nearly 1 fringe is obtained at the lower limit of the tests $(\mathrm{pH} 2)$ and continues at that rate to about $\mathrm{pH} 8$ and from there to $\mathrm{pH} 11.8$ the swelling rapidly changes to an attack of $3 \frac{11}{2}$ fringes. It was noted during the tests that the swelling that took place in the solution disappeared

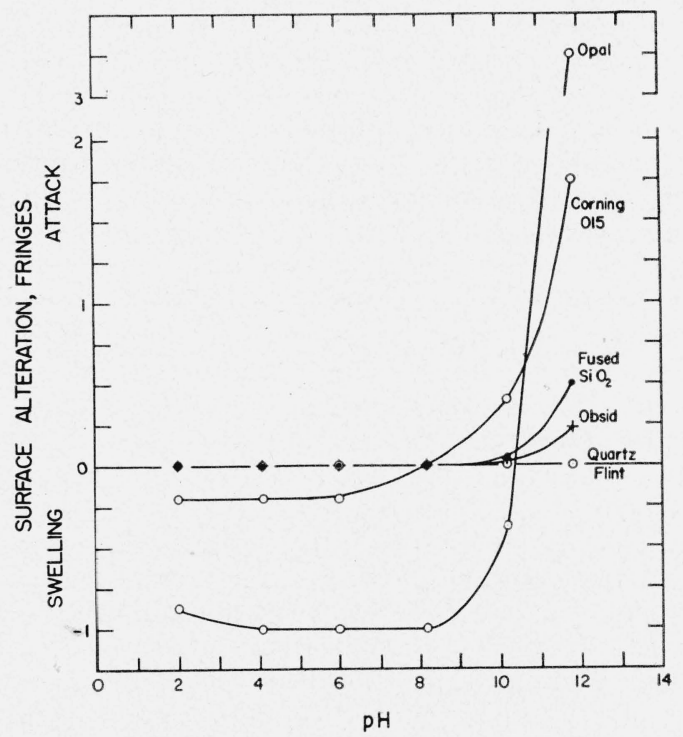

FIGURE 1. Relative chemical durabilities over the range $\mathrm{pH}$ \% to $\mathrm{pH} 11.8$ after exposure for 6 hours at $80^{\circ} \mathrm{C}$ in Britton buffers.

TABLE 1. Chemical durability, hygroscopicity, and interfacial uneven distribution of migratable ions for silicate materials

\begin{tabular}{|c|c|c|c|c|c|c|c|c|c|c|c|c|c|c|}
\hline \multirow{2}{*}{ Material } & \multicolumn{7}{|c|}{ Surface alterations for exposures of $6 \mathrm{hr}, 80^{\circ} \mathrm{C}$ at $\mathrm{pH}-$} & \multicolumn{2}{|c|}{ Water sorbed in- } & \multicolumn{5}{|c|}{$\begin{array}{l}\text { Excess } \mathrm{Ag}\left(\mathrm{NH}_{3}\right)_{2}^{+} \text {ions in surface of speci- } \\
\text { mens leached at pH } 4.1,80^{\circ} \mathrm{C} \text { in- }\end{array}$} \\
\hline & 2 & 4.1 & 6.0 & 8.2 & 10.2 & 11.8 & $\begin{array}{c}5 \% \\
\mathrm{NaOH}\end{array}$ & $1 \mathrm{hr}$ & $2 \mathrm{hr}$ & $0 \mathrm{hr}$ & $6 \mathrm{hr}$ & $24 \mathrm{hr}$ & $72 \mathrm{hr}$ & $144 \mathrm{hr}$ \\
\hline $\begin{array}{l}\text { Quartz } \\
\text { Flint } \\
\text { Fused } \mathrm{SiO}_{2} \\
\text { Obsidian } \\
\text { Pitchstone } \\
\text { Corning } 015 \\
\text { Pyrex } \\
\text { Opal }\left(\mathrm{SiO}_{2} . \mathrm{nH}_{2} \mathrm{O}\right)\end{array}$ & $\begin{array}{l}\text { Fringes } \\
\text { ND } \\
\text { ND } \\
\text { ND } \\
\text { ND } \\
310-S^{i} \\
\text { ND } \\
\text { h } 3 / 4+\mathrm{S}\end{array}$ & $\begin{array}{c}\text { Fringes } \\
\text { ND } \\
\text { ND } \\
\text { ND } \\
\text { ND } \\
210-\mathrm{S} \\
\text { ND } \\
1 \mathrm{~S}\end{array}$ & $\begin{array}{c}\text { Fringes } \\
\text { ND } \\
\text { ND } \\
\text { ND } \\
\text { ND } \\
2 / 10-5 \\
\text { ND } \\
1 \mathrm{~S}\end{array}$ & $\begin{array}{c}\text { Fringes } \\
\text { ND } \\
\text { ND } \\
\text { ND } \\
\text { ND } \\
\text { SCg } \\
\text { D, A } \\
1 \mathrm{~S}\end{array}$ & $\begin{array}{c}\text { Fringes } \\
\text { ND } \\
\text { ND } \\
\mathrm{D}^{\mathrm{d}}, \mathrm{A} \\
\mathrm{D}, \mathrm{A} \\
1 / 4+\mathrm{A} \\
114-\mathrm{A} \\
1 / 2-\mathrm{S}\end{array}$ & $\begin{array}{c}\text { Fringes } \\
\text { ND } \\
\text { ND } \\
1 / 2 \mathrm{~A} \\
\text { e } 1 / 4-\mathrm{A} \\
2-\mathrm{A} \\
13 / 4 \mathrm{~A} \\
31 / 4 \mathrm{~A}\end{array}$ & $\begin{array}{c}\text { Fringes } \\
\text { ND } \\
1 / 10 \mathbf{A}^{\mathrm{c}} \\
1 \mathrm{~A} \\
1 \mathrm{~A} \\
1 \mathrm{~A} \\
21 / 2 \mathrm{~A} \\
24 \mathrm{~A}\end{array}$ & $\begin{array}{c}\mathrm{mg} / \mathrm{cm}^{3} \\
4.2 \\
-4.2 \\
8.6 \\
115 \\
\overline{39}\end{array}$ & $\begin{array}{c}\mathrm{mg} / \mathrm{cm}^{3} \\
7.9 \\
-7.8 \\
14.2 \\
230^{--} \\
61\end{array}$ & \begin{aligned} & $M-e g / g \\
< & \mathrm{b} 0.1 \times 10^{-4} \\
<< & 0.1 \\
<.1 & \\
$\hdashline 5.8 & \\
52.3 & \end{aligned} & $\begin{array}{c}M-e q / g \\
-0.4 \times 10^{-4} \\
0.9 \\
.6 \\
23 \\
152\end{array}$ & \begin{tabular}{c}
$M-e g / g$ \\
$\cdots$ \\
$\cdots$ \\
$\cdots$ \\
\hdashline $.6 \times 10^{-4}$ \\
$\cdots \cdots$
\end{tabular} & \begin{tabular}{c}
$M-e g / g$ \\
$0.6 \times 10^{-4}$ \\
\hdashline 1.0 \\
0.9 \\
39.3 \\
166
\end{tabular} & $\begin{array}{l}M-e g / g \\
1.0 \times 10^{-4} \\
1.1 \\
1.5 \\
30.2 \\
167\end{array}$ \\
\hline
\end{tabular}

S ND, not detectable.

b $<$, less than the smallest titrateable increment.

- A, attack.

d D, dectable, but not measurable. e $14-$, slightly less than $1 / 4$

is, swelling.

SC, surface cut at the oil-buffer boundary.

b $3 / 4^{+}$, slightly more than $3 / 4$. 
as the specimen was exposed to the air. Therefore, additional tests were made, the results of which are shown in figure 2 (data given in table 2), where attack is plotted against the number of hours after removal of the samples from the solution. It can be seen that after a period of $5 \mathrm{hr}$ the initial swelling of more than $1 \frac{1}{2}$ fringes has changed to an appreciable attack, which leads to the conclusion that both solution and swelling had occurred during exposure. In figure 1 it can be seen that swelling is more rapid than attack for all values below $\mathrm{pH} 10.2$. This is shown more strikingly in figure 3 (data given in table 3), where surface alteration (attack, swelling) is plotted against time of exposure at $\mathrm{pH}$ 4.1. Also shown are the changes in the surface alterations of the same specimens, taken from the buffer and ex-

TABLE 2. Surface alteration of the two specimens of opal upon exposure to air after immersion in Britton buffer at $\mathrm{pH} 4.1$ for 24 hours at $80^{\circ} \mathrm{C}$

\begin{tabular}{|c|c|c|c|c|c|c|}
\hline \hline \multirow{2}{*}{$\begin{array}{c}\text { Sample } \\
\text { number }\end{array}$} & \multicolumn{6}{|c|}{ Surface alteration in- } \\
\cline { 2 - 6 } & $0 \mathrm{hr}$ & $2 \mathrm{hr}$ & $6 \mathrm{hr}$ & $9 \mathrm{hr}$ & $24 \mathrm{hr}$ & $48 \mathrm{hr}$ \\
\hline & $\begin{array}{c}\text { Fringes } \\
11 / 2 \mathrm{~S} \\
2-\mathrm{S}\end{array}$ & $\begin{array}{c}\text { Fringes } \\
3 / 4 \mathrm{~S}\end{array}$ & $\begin{array}{c}\text { Fringes } \\
1 / 10 \mathrm{~A} \\
1 / 10 \mathrm{~A}\end{array}$ & $\begin{array}{c}\text { Fringes } \\
1 / 4-\mathrm{A}\end{array}$ & $\begin{array}{c}\text { Fringes } \\
1 / 4+\mathrm{A} \\
1 / 2-\mathrm{A}\end{array}$ & $\begin{array}{c}\text { Fringes } \\
1 / 1+\mathrm{A} \\
1 / 2-\mathrm{A}\end{array}$ \\
\hline
\end{tabular}

s Symbols explained in table 1. posed to the atmosphere for varying lengths of time. From this curve it appears that after about $50 \mathrm{hr}$ the amount of swelling approaches a maximum. In other words, the extent of attack is equal to or greater than the extent of swelling. If the swelling as noted in these curves is caused by the uneven distribution of migratable ions, the osmotic pressure should be

TABLE 3. Effect of time on the swelling of opal in Britton buffer at $\mathrm{pH} 4.1$ and $80^{\circ} \mathrm{C}$, and the surface alteration after removal from the buffer and exposure in air

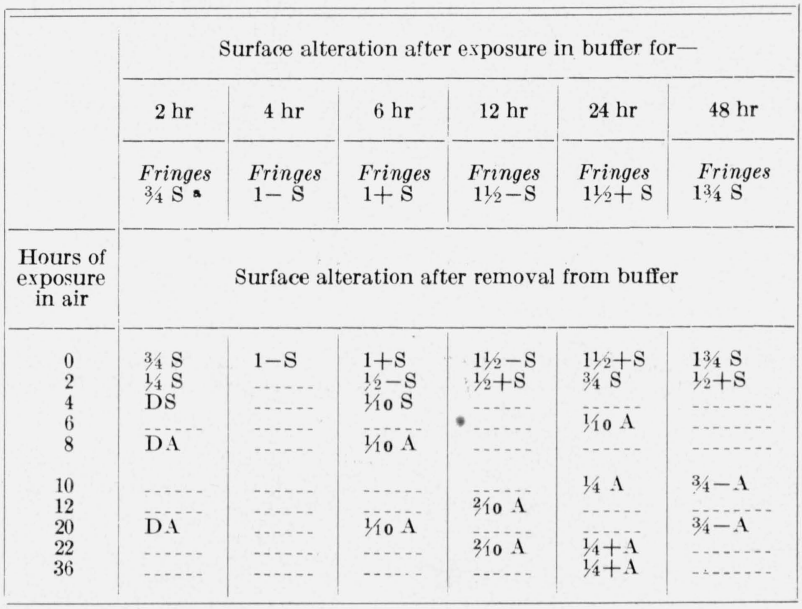

s Symbols explained in table 1.

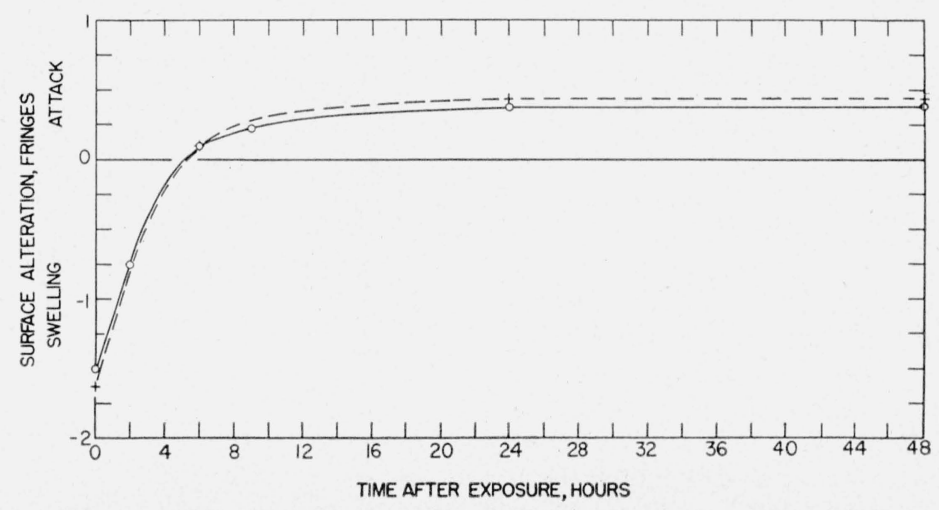

Figure 2. Surface alteration of two specimens of opal in air after exposure to Britton buffer solution at $\mathrm{pH} 4.1$ for 24 hours at $80^{\circ} \mathrm{C}$.

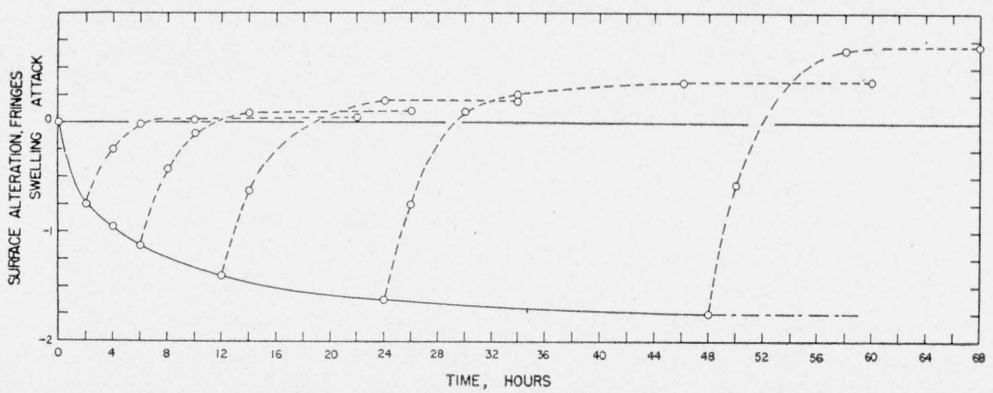

Figure 3. Typical surface alterations of opal with time of exposure in Britton buffer solution at $\mathrm{pH} 4.1$ at $80^{\circ} C$ followed by exposure in air. 


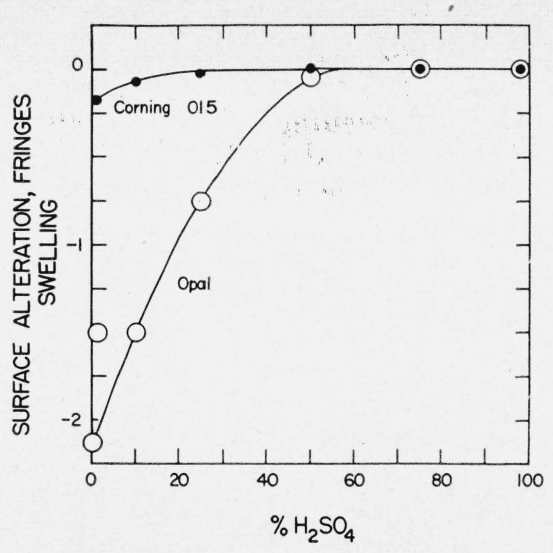

FIgure 4. Typical reduction of swelling of opal and Corning 015 by increased concentration of electrolyte, exposed for 6 hours at $80^{\circ} \mathrm{C}$.

TABLE 4. Surface alteration of opal and Corning 015 glass in sulfuric-acid solutions of various concentrations for 6 hours at $80^{\circ} \mathrm{C}$

\begin{tabular}{|c|c|c|}
\hline \multirow{2}{*}{$\mathrm{H}_{2} \mathrm{SO}_{4}$} & \multicolumn{2}{|c|}{ Surface alteration } \\
\hline & Opal & $\underset{015}{\text { Corning }}$ \\
\hline Percent & Frnnges & Fringes \\
\hline 0.1 & $2+\mathrm{S}^{2}$ & $2 / 10-S$ \\
\hline $\begin{array}{l}1.0 \\
10.0\end{array}$ & $\begin{array}{l}11 / 2 \mathrm{~S} \\
11 / 2 \mathrm{~S}\end{array}$ & $\begin{array}{l}2 / 10-S \\
1 / 10-S\end{array}$ \\
\hline 25.0 & & \\
\hline 50.0 & $\mathrm{ND}, \mathrm{SC}$ & ND \\
\hline 75.0 & ND, SC & ND \\
\hline 98.0 & ND, SC & ND \\
\hline
\end{tabular}

s Symbols explained in table 1 .

reduced by high concentrations of electrolytes in accord with the Donnan equation for osmotic pressure [7]. This effect is shown in figure 4 (data given in table 4), where surface alteration of opal and Corning 015 is plotted against concentration of $\mathrm{H}_{2} \mathrm{SO}_{4}$. It can be seen that at 0.1 percent $\mathrm{H}_{2} \mathrm{SO}_{4}$ a swelling of greater than 2 fringes is obtained, and at 65-percent $\mathrm{H}_{2} \mathrm{SO}_{4}$ the amount of swelling has been reduced until it is no longer detectable. It is realized that considering 65-percent $\mathrm{H}_{2} \mathrm{SO}_{4}$ as a high concentration of electrolyte in terms of the Donnan theory of membrane equilibria is questionable and that any one of a number of other explanations could suffice [3].

The hygroscopicity of the samples is plotted in yure 5 (data given in table 1) as water sorbed in $\mathrm{mg} / \mathrm{cm}^{3}$ against time in hours. Note that the relative positions of Corning 015 and opal in this figure have been reversed from that in figure 1 , indicating that the surface alteration (swelling) of the opal results from some factor other than its hygroscopic property. In other words, hygroscopicity is not a reliable indicator of chemical durability.

In figure 6 (data given in table 1 ) the excess $\mathrm{Ag}\left(\mathrm{NH}_{3}\right)_{2}+$ ions in milliequivalents per gram (hereafter designated as M-cq/g) appearing in the surface is plotted against time of leaching at pH 4.1 at $80^{\circ} \mathrm{C}$. The relative positions of these curves are compatible with those of surface alteration shown in figure 1 .

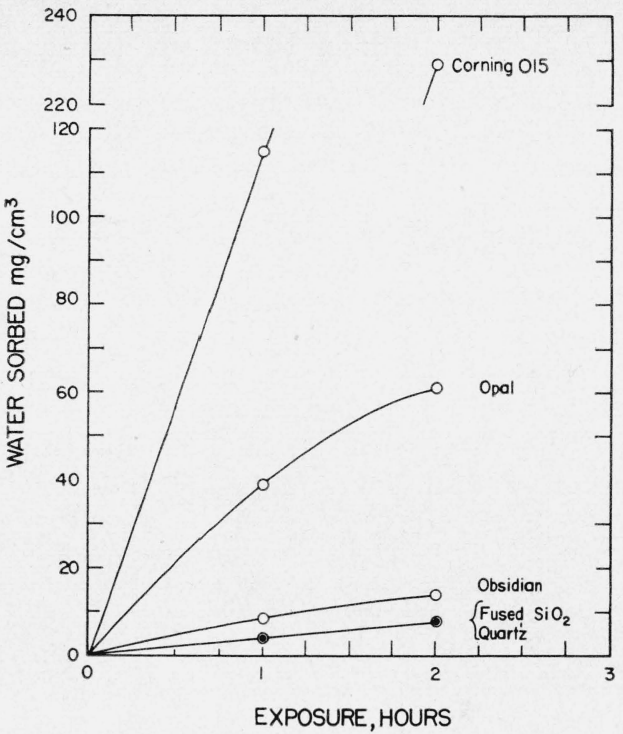

FiguRE 5. Hygroscopicity (water sorbed) for quartz, fused $\mathrm{SiO}_{2}$, obsidian, opal, and an electrode glass (Corning 015) after exposure in an atmosphere of 98-percent relative humidity.

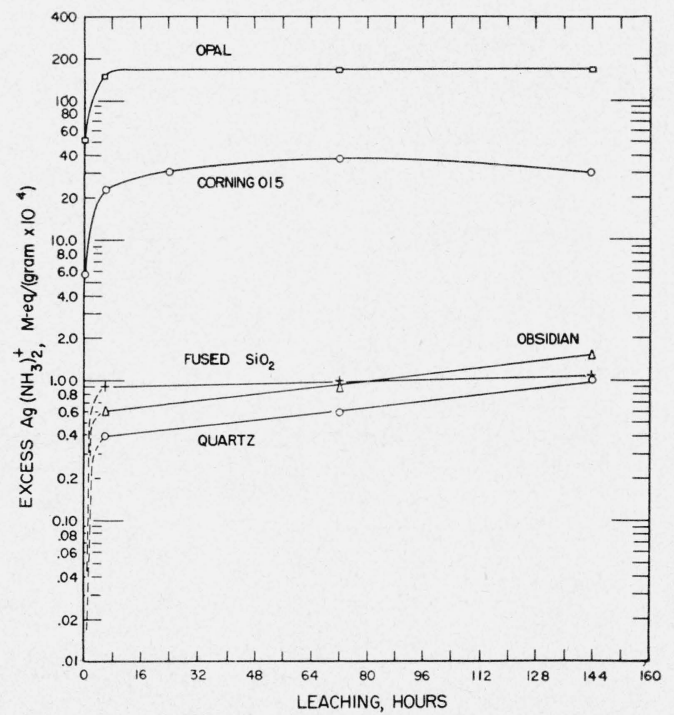

FIgURE 6. Uneven distribution of migratable ions at the interface between the surface layer and the outer solution after various periods of leaching in Britton buffer at $\mathrm{pH} 4.1$ at $80^{\circ} \mathrm{C}$ using $\mathrm{Ag}\left(\mathrm{NH}_{3}\right)_{2}^{+}$and $\mathrm{Br}^{-}$as the indicator ions.

This uneven distribution of the migratable ions is caused by the nonmigratable negative charged silicate ions acting as their own semipermeable membrane, and thus causing a definite osmotic pressure across the opal-solution interface.

It is well recognized that chemical attack plays a considerable part in the weathering of rocks and minerals. These tests strongly point out the fact, not always realized, that the weaker acids and bases or even neutral salts may sometimes be a much more destructive force than concentrated solutions. These studies also indicate that another phenomenon, os. mosis, plays a very important and persistent role ir 
the weathering of numerous rocks and minerals. The interferometer procedure might we!l be used to study the relative resistance of many of the rockforming minerals to acids and bases over a much wider time and concentration range than was done here.

\subsection{Alkali Aggregate Reaction}

High-alkali cements are known to react with certain aggregates, particularly opal, used in concrete [8]. This reaction causes a swelling and subsequent deterioration of the concrete structure. Hansen [9] has postulated that the cement paste might act as a semipermeable membrane, which would allow the alkalies to migrate through the concrete and react with the opal. The reaction product would not be capable of diffusing through the hardened cement paste. Thus osmotic pressures would be built up, which could cause disintegration of the concrete. A modification of this hypothesis as advanced by Parsons and Insley [10] suggested that a reaction takes place at the walls of the pores in the concrete to form a membrane impermeable to further migration of alkali silicates. The authors have considered the possibility that the opal grains might act as their own semipermeable membrane. However, the interferometer shows that expansion of the opal itself occurs in the acid and not in the alkaline range. Any expansion in the alkaline range must be because of some reaction products or to osmotic pressures set up through some membrane surrounding the ir dividual opal grain rather than to any Donnan membrane equilibria in the opal itself. Another interpretation of this effect has been advanced by Vivian [11], who believes that alkalies react with opal to form a gel that absorbs water, causing swelling of the gel and subsequent failure of the concrete.

\subsection{Porcelain Enamels}

In figure 7 (data given in table 5) is plotted the chemical durability of three commercial porcelain enamels, a class $A$ acid resistant, a class $D$ acid resistant, and a hot-water tank enamel of a type used in the manufacture of the so-called glass-lined tanks. (Hereafter referred to as glass-lined tank enamel.) [12]. The difference in durability in both the acid and alkaline range can be observed from these curves.

The hygroscopicity of these enamels is shown in figure 8 (data given in table 6 ) and is seen to be greater than that of Pyrex but much less than that of Corning 015.

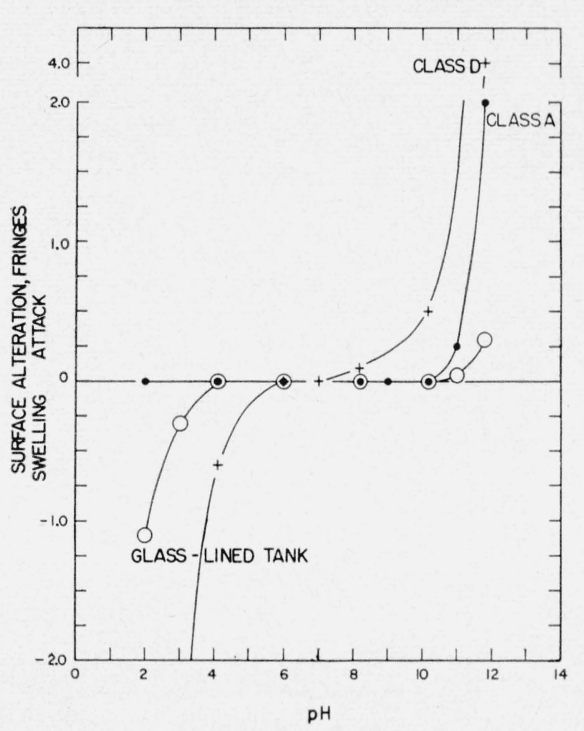

, Glass-lined tank; $\mathbf{O}$, class $\mathrm{A}$, and + , class $\mathrm{D}$ acid-resistent enamels.

Figure 7. Chemical durability over the range from $\mathrm{pH} 2$ to 11.8 of three types of porcelain enamels, after exposure for 6 hours at $80^{\circ} \mathrm{C}$ in Britton buffers.

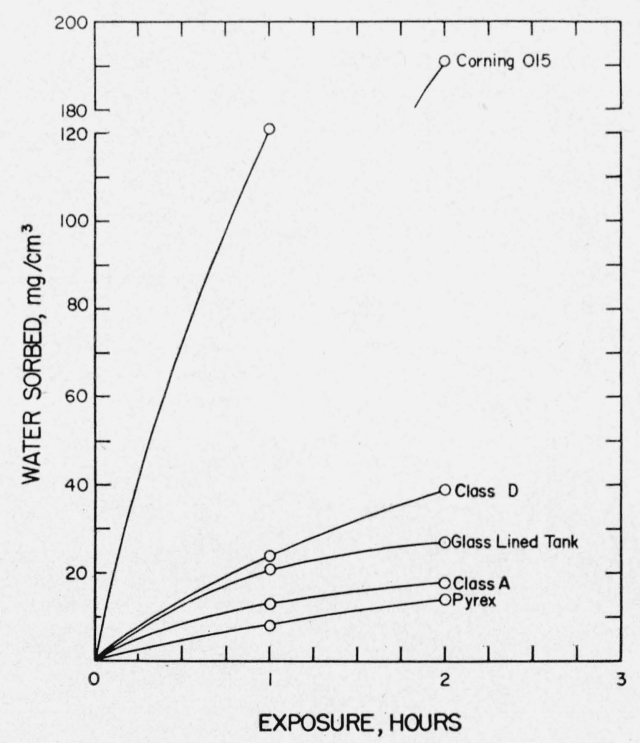

FIguRe 8. Hygroscopicity (water sorbed) of three typical porcelain enamels compared with two commercial glasses, after exposure to a relative humidity of 98 percent.

TABLE 5. Chemical durability of three types of porcelain enamel

\begin{tabular}{|c|c|c|c|c|c|c|c|c|c|c|}
\hline \multirow{2}{*}{ Enamel } & \multicolumn{10}{|c|}{ Surface alteration at $\mathrm{pH}-$} \\
\hline & 2.0 & 3.0 & 4.1 & 6.0 & 7.0 & 8.2 & 9.0 & 10.2 & 11.0 & 11.8 \\
\hline $\begin{array}{l}\text { Acid resistant, class A } \\
\text { Glass-lined tank }\end{array}$ & $\begin{array}{c}\text { Fringes } \\
\text { a ND } \\
1+\mathrm{S}\end{array}$ & $\begin{array}{c}\text { Fringes } \\
1 / 4+\mathrm{S}\end{array}$ & $\begin{array}{l}\text { Fringes } \\
\text { ND } \\
\text { ND }\end{array}$ & $\begin{array}{l}\text { Fringes } \\
\text { ND } \\
\text { ND }\end{array}$ & Fringes & $\begin{array}{l}\text { Fringes } \\
\text { ND } \\
\text { ND }\end{array}$ & $\begin{array}{c}\text { Fringes } \\
\text { ND }\end{array}$ & $\begin{array}{l}\text { Fringes } \\
\text { ND } \\
\text { ND }\end{array}$ & $\begin{array}{c}\text { Fringes } \\
1 / 4 \mathrm{~A} \\
\text { D A }\end{array}$ & $\begin{array}{c}\text { Fringes } \\
2 \mathrm{~A} \\
1 / 4 \mathrm{~A}\end{array}$ \\
\hline Acid resistant, class D & $144 \mathrm{~S}$ & $36 \mathrm{~S}$ & $1 / 2+\mathrm{S}$ & ND & ND & $1 / 10 \mathrm{~A}$ & & $1 / 2 \mathrm{~A}$ & & $4 \mathrm{~A}$ \\
\hline
\end{tabular}

a Symbols explained table 1 . 
TABLE 6. Comparison of the hygroscopicities for three types of porcelain enamels and two commercial glasses

\begin{tabular}{|c|c|c|}
\hline \multirow{2}{*}{ Specimen } & \multicolumn{2}{|c|}{ Water sorbed in- } \\
\hline & $1 \mathrm{hr}$ & $2 \mathrm{hr}$ \\
\hline $\begin{array}{l}\text { Porcelain enamels: } \\
\text { Class A, acid resistant } \\
\text { Glass-lined tank } \\
\text { Class D, acid resistant }\end{array}$ & $\begin{array}{l}m g / \mathrm{cm}^{3} \\
13 \\
21 \\
24\end{array}$ & $\begin{array}{l}m g / \mathrm{cm}^{3} \\
18 \\
27 \\
39\end{array}$ \\
\hline $\begin{array}{l}\text { Glasses: } \\
\quad \text { Corning } 015 \ldots \\
\text { Pyrex } 7740\end{array}$ & $\begin{array}{r}121 \\
8\end{array}$ & $\begin{array}{r}191 \\
14\end{array}$ \\
\hline
\end{tabular}

The chemical durability of the class $\mathrm{A}$ enamel at high concentration of acids is shown in figure 9 (data given in tables 5 and 7 ), and the repression of swelling of the tank enamel at high concentration of electrolytes is shown in figure 10 (data given in table 8). The uneven distribution of the migratable ions for the class D enamel gave the low value of less than $0.2 \times 10^{-4} \mathrm{M}-\mathrm{eq} / \mathrm{g}$ with no leach, and the very high value of $415 \times 10^{-4} \mathrm{M}-\mathrm{eq} / \mathrm{g}$ after $6 \mathrm{hr}$ of leaching at $\mathrm{pH} 4.1$. This value is 46 times greater than for the glass-lined tank enamel and is a very striking example of the sensitivity of this test.

TABLE 7. Chemical durability of two commercial porcelain enamels in aqueous solutions of $\mathrm{H}_{2} \mathrm{SO}_{4}$ and $\mathrm{CH}_{3} \mathrm{COOH}$

\begin{tabular}{|c|c|c|c|c|c|c|}
\hline & & & \multicolumn{4}{|c|}{ Surface alteration } \\
\hline \multicolumn{3}{|c|}{ Solution } & \multicolumn{2}{|c|}{$\begin{array}{l}\text { Class A, acid- } \\
\text { resistant }\end{array}$} & \multicolumn{2}{|c|}{$\begin{array}{l}\text { Glass-lined } \\
\operatorname{tank}\end{array}$} \\
\hline \multirow{8}{*}{$\begin{array}{c}\text { Percent } \\
0.1 \\
1.0 \\
10.0 \\
25.0 \\
50.0 \\
75.0 \\
96.0 \\
98.0\end{array}$} & $\mathrm{H}_{2} \mathrm{SO}_{4}$ & $\mathrm{CH}_{3} \mathrm{COOH}$ & $\mathrm{H}_{2} \mathrm{SO}_{4}$ & $\mathrm{CH}_{3} \mathrm{COOH}$ & $\mathrm{H}_{2} \mathrm{SO}_{4}$ & $\mathrm{CH}_{3} \mathrm{COOH}$ \\
\hline & $\mathrm{pH}$ & $\mathrm{pH}_{2}$ & Fringes & Fringes & Fringes & Fringes \\
\hline & $\begin{array}{l}1.7 \\
0.75\end{array}$ & $\begin{array}{l}2.7 \\
2.5\end{array}$ & $\begin{array}{l}{ }^{a} \text { ND } \\
\text { ND }\end{array}$ & & & \\
\hline & 0 & & ND & (n).... & (b) & (b) \\
\hline & -0.62 & 1 & ND & - & ND & \\
\hline & $\begin{array}{l}-1.49 \\
-2.45\end{array}$ & $\begin{array}{l}1.3 \\
0.6\end{array}$ & $\begin{array}{l}\text { ND } \\
\text { ND }\end{array}$ & $\begin{array}{l}\text { ND } \\
\text { ND }\end{array}$ & ND & ND \\
\hline & -8.1 & & ND & & ND & 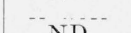 \\
\hline & - & -2.2 & -... & & & $\mathrm{ND}$ \\
\hline
\end{tabular}

a Symbols explained in table 1.

b The iron backing of the glass-lined tank enamel was severely attacked at 0.1 to 25 percent $\mathrm{H}_{2} \mathrm{SO}_{4}$ and $\mathrm{CH}_{3} \mathrm{COOH}, \mathrm{H}_{2}$ was evolved, which chipped and shattered the enamel, thus destroying the specimen.

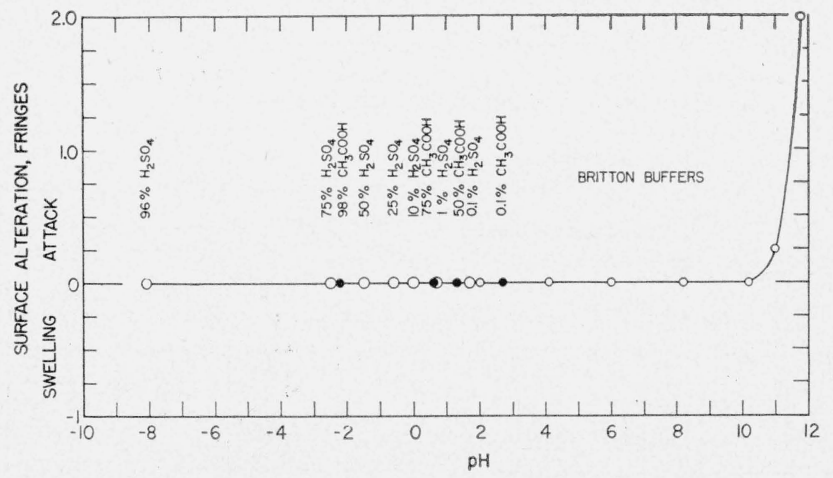

Figure 9. Chemical durability of class A acid-resistant porcelain enamel over the range $\mathrm{pH}-8$ to $\mathrm{pH} 12$ after exposure for 6 hours at $80^{\circ} \mathrm{C}$.

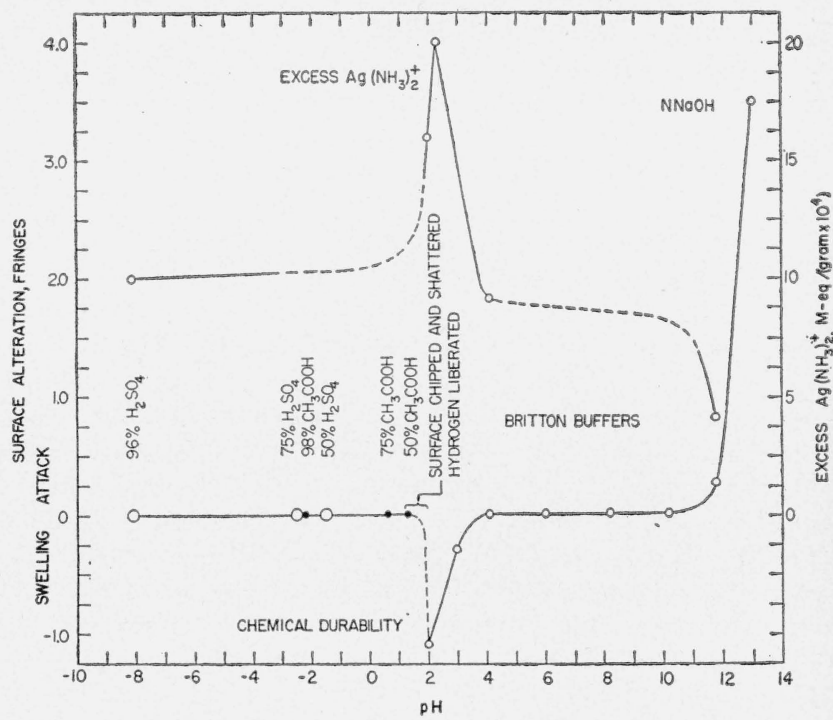

FiguRe 10. Comparison of the uneven distribution of migratable ions at the enamel-solution interface with the chemical durability of a porcelain enamel used in glass-lined tanks, after exposures for 6 hours at $80^{\circ} \mathrm{C}$.

TABLE 8. Uneven distribution of $\mathrm{Ag}\left(\mathrm{NH}_{3}\right)_{2}^{+}$at the enamelsolution interface after leaching in various solutions for 6 hours at $80^{\circ} \mathrm{C}$

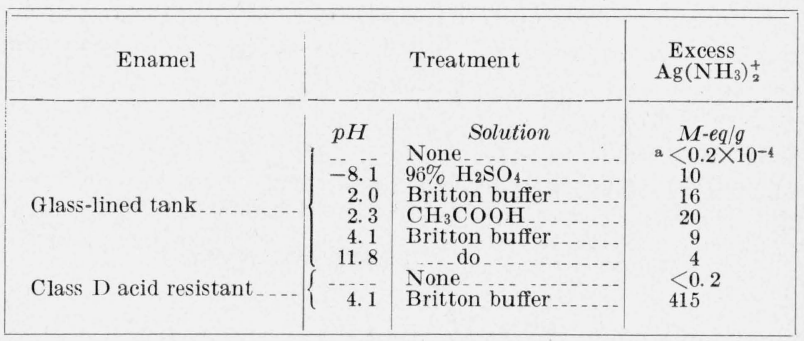

a Symbols explained in table 1.

Because the composition of the enamels was not known in detail, it is difficult to discuss the mechanism or nature of the attack indicated by the interferometer data. The evidence, however, that porcelain enamel is subject to alkaline attack correlates well with field tests that have been made on enamelware [13]. It appears that the nature of the attack on the enamels is analagous to that on commercial glasses. It would seem, then, that some of the problems of the chemical durability of different enamels could be advantageously studied by these techniques.

\subsection{Metals}

Although the interferometer has been used widely in science and industry, the procedure for measuring the chemical durability has not been applied to the study of the corrosive resistance of metals and alloys to acids and bases of all concentrations. The chemical durability of cold-rolled steel, aluminum, copper, 


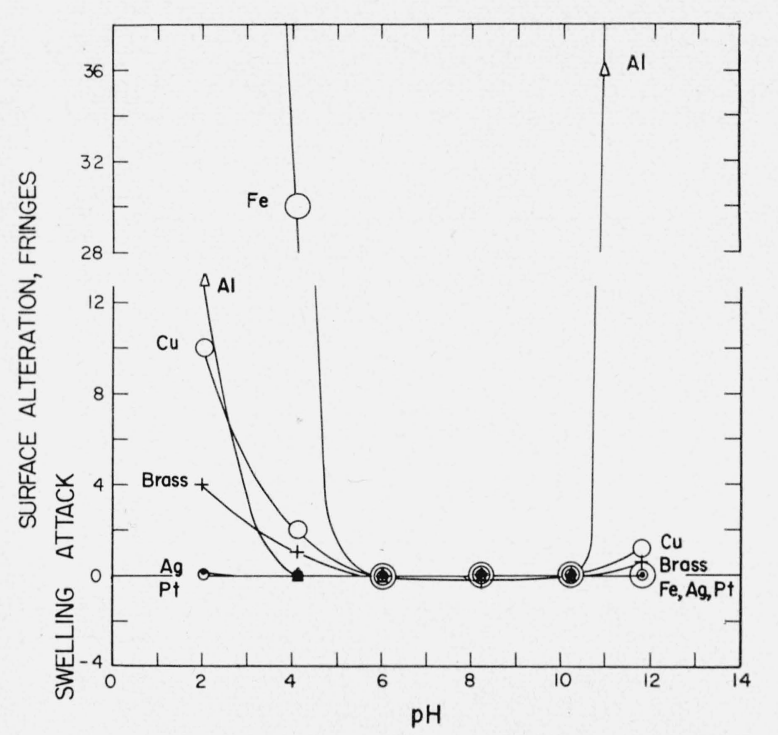

Figure 11. Chemical durability of various metals and alloys after exposure to Britton buffers for 6 hours at $80^{\circ} \mathrm{C}$.

TABLE 9. Chemical durability of metals exposed to Britton buffers for 6 hours at $80^{\circ} \mathrm{C}$

\begin{tabular}{|c|c|c|c|c|c|c|c|}
\hline \multirow{2}{*}{ Metal } & \multicolumn{7}{|c|}{ Surface alteration at $\mathrm{pH}-$} \\
\hline & 2.0 & 4.1 & 6.0 & 8.2 & 10.2 & 11.0 & 11.8 \\
\hline $\begin{array}{l}\text { Cold-rolled } \\
\text { steel }\end{array}$ & $\begin{array}{l}\text { Fringes } \\
\text { a } 360 \mathrm{~A}\end{array}$ & $\begin{array}{c}\text { Fringes } \\
30 \mathrm{~A}\end{array}$ & $\begin{array}{l}\text { Fringes } \\
\text { ND }\end{array}$ & $\begin{array}{c}\text { Fringes } \\
\text { ND }\end{array}$ & $\begin{array}{l}\text { Fringes } \\
\text { ND }\end{array}$ & Fringes & $\begin{array}{c}\text { Fringes } \\
\text { ND }\end{array}$ \\
\hline Aluminum & $13 \mathrm{~A}$ & ND & ND & ND & $\begin{array}{c}\text { ND, SC, } \\
\text { black }\end{array}$ & $36 \mathrm{~A}$ & $390 \mathrm{~A}$ \\
\hline Copper .... & $10 \mathrm{~A}$ & $2 \mathrm{~A}$ & ND & ND & $\begin{array}{l}\text { ND } \\
\text { ND }\end{array}$ & ..... & $\begin{array}{l}1+\mathrm{A} \\
1,2 \mathrm{~A}\end{array}$ \\
\hline Silver........ & $1 / 10+\mathrm{A}$ & ND & ND & NDD & ND & (n..... & ND \\
\hline Platinum . & ND & ND & ND & ND & ND & $\ldots$ & ND \\
\hline
\end{tabular}

Symbols explained in table 1.

brass, silver, and platinum is shown in figure 11 (data given in table 9). Because of the rapid reaction of some of the samples, exposures as short as 1 min were required, and the results were extrapolated to $6 \mathrm{hr}$ in order to put all the data on a comparable basis. The swelling of brass and the slight attack on silver might be more convincingly demonstrated by increasing the exposure time to $24 \mathrm{hr}$ or more. When aluminum was treated at $\mathrm{pH} 10.2$, a hard black almost nonreflecting coating was formed, although no dimensional change could be detected by the interferometer. In fact, in many cases there was a color change in the treated area but with no detectable dimensional change. Hass [14] states that the oxide film on aluminum may be as thin as $20 \mathrm{~A}$. Because the lower limit of resolution of the interferometer is about $30 \mathrm{~A}$, no swelling could be observed. It is also interesting to note that the points at which surface alteration becomes detectable correspond very closely to the values determined by Wells [15], namely, $\mathrm{pH} 3.95$ and $\mathrm{pH}$ 10.94, where aluminum hydroxide becomes sol- uble in the acid and alkaline regions. In several samples where a slight attack or dull matt swollen surface had resulted, repeated gentle polishing on $4 / 0$ emery paper increased the observable attack in the exposed area to a definite maximum. This indicates that chemical attack had progressed to a considerable depth below the surface. In all cases the maximum attack noted after the emery-paper treatment was reported as the chemical durability.

The results on all metals tested show good corrosive resistance from $\mathrm{pH} 6$ to $\mathrm{pH} 10$. There is, however, a very definite attack on all the metal surfaces except platinum at $\mathrm{pH}$ values below this range. Because of the sensitivity of the interferometer measurements, the method offers a means of studying the corrosive resistance of metals and alloys under very diverse conditions.

\section{References}

[1] Donald Hubbard and Edgar H. Hamilton, Studies of the chemical durability of glass by an interferometer method, J. Research NBS 27, 143 (1941) RP1409.

[2] Donald Hubbard, Mason H. Black, Sylvanus F. Holly, and Gerald F. Rynders, Electrode function ( $\mathrm{pH}$ response) hygroscopicity and chemical durability of soda-potash-silica glasses, J. Research NBS 46, 168 (1951) RP2189.

[3] Donald Hubbard and Richard G. Goldman, Heterogeneous equilibria at the glass electrode-solution interface, J. Research NBS 48, 428 (1952) RP2333.

[4] H. T. S. Britton, Hydrogen ions, I, 3d ed., p. 313 (D. Van Nostrand Co., New York, N. Y., 1943).

[5] James W. McBain, The mechanism of the adsorption (sorption) of hydrogen on carbon, Phil. Mag. 18, 916 (1909); Z. Physik. Chem. 68, 471 (1909).

[6] Donald Hubbard, Hygroscopicity of optical glasses as an indicator of serviceability, J. Research NBS 36, 365 (1946) RP1706.

[7] Samuel Glasstone, Textbook of physical chemist:y, 2d ed., pp 1259-1262 (D. Van Nostrand Co., Inc., New York, N. Y.)

[8] T. E. Stanton, Expansion of concrete through reaction between cement and aggregate, Proc., Am. Soc. Civil Engrs. 66, 1781-1811 (1940).

[9] W. C. Hansen, Studies relating to mechanism by which alkali reaction produces expansion in concrete, J. Am. Concrete Inst. Proceedings, 40, 213-227 (Jan. 1944)

[10] Willard H. Parsons and H. Insley, Aggregate reaction with cement alkalies, J. Am. Concrete Inst. 19, 625-631 (1948).

[11] H. E. Vivian, Studies in cement aggregate reaction, Part XV Commonwealth Scientific and Industrial Research Organization, Australia, Bul. No. 256, p. 78 (1950).

[12] Test for acid resistance of porcelain enamels, Part 1 (Flatware, Porcelain Enamel Institute, 1346 Conn. Ave. NW, Wash. 6, D. C.)

[13] J. R. Crandall, J. C. Richmond, A. G. Eubanks, and W. N. Harrison Progress report on the correlation of service data with laboratory tests on porcelain enamels, given at ACS meeting Apr. 1952 Pittsburgh, Pa.

[14] G. Hass, Growth and structure of thin oxide layers on aluminum, Optik 1, 134-43 (1946).

[15] Lansing Wells, Reaction of water on calcium aluminate, BS J. Research 1, table 15 (1928) RP34.

Washington, October 10, 1952. 